University of Nebraska - Lincoln

DigitalCommons@University of Nebraska - Lincoln

Marketing Department Faculty Publications

Marketing Department (CBA)

2-2009

\title{
Underdog consumption: An exploration into meanings and motives
}

Lee Phillip McGinnis

Washburn University

James W. Gentry

University of Nebraska-Lincoln, jgentry@unl.edu

Follow this and additional works at: https://digitalcommons.unl.edu/marketingfacpub

Part of the Marketing Commons

McGinnis, Lee Phillip and Gentry, James W., "Underdog consumption: An exploration into meanings and motives" (2009). Marketing Department Faculty Publications. 9.

https://digitalcommons.unl.edu/marketingfacpub/9

This Article is brought to you for free and open access by the Marketing Department (CBA) at DigitalCommons@University of Nebraska - Lincoln. It has been accepted for inclusion in Marketing Department Faculty Publications by an authorized administrator of DigitalCommons@University of Nebraska - Lincoln. 
Published in Journal of Business Research 62:2 (February 2009), pp. 191-199; doi: 10.1016/j.jbusres.2008.01.026

Copyright $@ 2008$ Elsevier Inc. Used by permission.

Submitted June 1, 2007; revised November 1, 2007; accepted January 1, 2008; published online March 4, 2008.

\title{
Underdog consumption: An exploration into meanings and motives
}

\author{
Lee Phillip McGinnis \\ Department of Marketing, Washburn University, \\ Henderson 310-K, 1700 SW College Ave, Topeka, KS 66621, USA; \\ Corresponding author - tel 785 670-1894, fax 785 670-1063, email lee.mcginnis@washburn.edu \\ James W. Gentry \\ Department of Marketing, University of Nebraska-Lincoln, \\ Lincoln, NE 68588-0492, USA; email jgentry@unl.edu
}

\begin{abstract}
Marketers frequently position business concerns - whether brands, teams, or stores - as the non market-dominant entity (or the "underdog"). This article examines the motives for underdog support through in-depth interviews and a focus group. Findings suggest that underdog consumers support underdogs out of empathy, as a way to ensure the maintenance of equal opportunity in competition, and as a way to provide personal inspiration. Some motives for underdog support can be interpreted to be anticonsumption (or, at least, anti-corporate) in nature. On the other hand, many underdog consumers support and identify with underdogs not necessarily as a way to keep the top dog down, but as a means to keep the little guy competing. Rather than solely "vote-against" behavior, "vote-for" behavior is very evident as well.
\end{abstract}

Keywords: anti-consumption, creolization, counter-conformity, glocalization, identification, underdogs

\section{Introduction}

Many sports fans and non-sports fans alike frequently root for and/or support the underdog. Several of Hollywood's most popular movies have told inspiring underdog stories; for example Rudy, Rocky, Sea Biscuit, and Million Dollar Baby. Many popular sports teams have been successful as underdogs, including the loveable losers, the Chicago Cubs. The fascination Americans have with underdogs extends to famous personalities including Abraham Lincoln, Ronald Reagan, Oprah Winfrey, and Bill Clinton. These individuals represent people who have overcome underdog status to become successful. Marketers such as Avis with "We try harder" and Volkswagen with self-deprecating headlines (e.g., "Ugly is only skin deep") have used underdog-type appeals in establishing effective positioning strategies, the latter example using what Holt (2004) describes as irony and reflexive acknowledgement.

Consumers may identify with "underdog" brands as a possible show of anti-consumptive behavior for a variety of reasons. Holt's (2002) brand counterconformists avoid the influence of popular brands in pursuit of individual sovereignty. Kozinets' (2002) Burning Man participants attempt to temporarily leave the market to gain sovereignty, while Kozinets' (2001) "Trekkies" seek legitimization for their marginalized practices. O'Guinn (1991) shows how marginalized fan club members are motivated to support their chosen celebrity in hopes of touching greatness. Holt (2002) indicates that popular brands, even from those companies that have been extremely loyal to the marketing concept, are realizing anti-brand sentiment from consumers in the postmodern era.

Thompson and Arsel's (2004) "glocalization" and Ger and Belk's (1996) "creolization" deal with this process in a more dynamic fashion. Thompson and Arsel note that glocalization is "a needed corrective to the calamitous view of global capitalism as a culture-crushing juggernaut" (p. 631). Both glocalization and creolization note the attraction of global brands, especially when they first become available in areas which formerly did not have them. Over time, consumers may choose to re-purchase their former favorite brands or return to their formerly preferred local retailers. Both glocalization and creolization note that this occurrence is often a blending process, rather than just an either/or decision. Glocalization, at least as discussed in the findings of Thompson and Arsel's study of consumers of Starbucks' local compet- 
itors in Madison Wisconsin, has a strong "anti-corporate" element, as their café flâneurs noted that they would be embarrassed to be seen in a Starbucks. Ger and Belk's creolization is more an acknowledgment of strong attraction to the old familiar entity. To use a political metaphor, glocalization would involve more the voting against the market-dominant entity, whereas creolization involves more the voting for the less well-known entity. This study of the underdog will try to tease out both elements involving anti-top dog attitudes and those involving a more pro-active favoring of the underdog.

The studies discussed previously (e.g., Holt, 2002) cover underdog consumption, but appear to fall somewhat short in explaining why some people continuously support underdog brands, people, stores, and other objects across domains when concerns such as quality, variety, price, and even one's "face" may be compromised. In this study, the authors explore the motives and meanings of underdog consumption and how underdog consumers negotiate their self-identities even when confronted with alternatives of higher quality, wider variety, and/or cheaper prices.

\section{Literature review}

Identity studies from the sports fan literature suggest that people who identify with an underdog sports team or athlete do so to fulfill some kind of a social role and are demonstrating group-derived behavior (Fisher and Wakefield, 1998). These people may either support a team due to perceived performance or other factors such as attractiveness of the group's members, team personalities, proximity, or a love for the game. This group downplays the importance of winning because they do not want the negative connotations associated with a losing team to be connected to them. Findings suggest that associating positively with losing is not only unlikely but also highly undesirable and nonproductive.

Basking in reflected glory or BIRGing studies (Cialdini et al., 1976) suggest that when people's identities become susceptible to public scrutiny, people will most likely try to identify with a positive entity. Further research in this area suggests that sports fans internalize the attribute of winning and externalize the attribute of losing, with the former more inclined to say "we won" and the latter inclined to say "they lost" (Grove et al., 1991; Mann, 1974; Wann and Dolan, 1994). These findings indicate that losing and/or identifying with losers is, again, highly undesirable. Thus, BIRGing reflects attraction to global brands, and some consumers' desires to possess them. Possessing the brand can be of such importance that consumers may voluntarily purchase counterfeit versions of them.

Further research suggests, though, that in order to reconcile one as being an underdog without creating dissonance (Cialdini et al., 1976), underdog status support and/or selfconcept has to be framed in a positive manner. Few people, in other words, should want to view themselves or the entities they support as pure losers. This finding suggests, then, that a certain amount of teasing, or glimmers of hope (MacInnis and de Mello, 2005), may be needed to keep support- ers excited about the prospects of winning and about maintaining a positive self-image. Underdogs need to come close upon occasion or at least show flashes of potential in order to merit support; otherwise they are just losers and nobody expects anything from them. This support of entities performing poorly in general is not evident in all domains; as will be discussed in the findings, such support was not found for stocks or for politicians.

Holt's (2002) discussion of how brands are under attack by society's emerging countercultural movement addresses an anti-consumption-type motive to support underdog-type brands. For example, Holt describes how overt commercial motives hurt the images of today's brands and that postmodern consumers may use brands less as a way of establishing personal sovereignty. Holt (2004) discusses Snapple's positioning as anti-corporate and anti-elitist, attributing the brand's success in part to its resonation with the brand's audience and their desires to be free from ties to certain brands. In this sense, support for Snapple and other such brands may be driven by the need to keep the top dog brands at bay in establishing a more fair and competitive marketplace.

An underdog, by definition, cannot exist unless an alternative that is generally recognized as being superior (or at least bigger) on some dimension is present. Preference for the underdog may represent the rejection of that superior alternative, the top dog, or the possibility that trial of the top dog helped consumers crystallize their preferences for certain attributes offered uniquely by the underdog. For example, Thompson and Arsel's (2004) informants were liberal politically, and found the local coffee houses' flexibility to be active in political causes very appealing compared to the more "corporate," politically-neutral environment of a Starbucks.

Related to a consumer's motive to avoid mass appeal type products is the desire for uniqueness. Tian et al. (2001) describe three different dimensions of uniqueness. The first, creative choice counter-conformity, concerns the deliberate attempt to buy clothes and other consumer goods that are different from the established norm, but are still viewed as socially acceptable. The second dimension, unpopular choice counter-conformity, is the tendency to make consumer choices that position the individual as distinct from the group in a way that seeks social disapproval. The third, avoidance of similarity, is the intentional avoidance of commonly used products or brands, irrespective of whether these choices meet social approval. While the first two choices appear to be driven by the need to be individualistic, the latter choice appears to be driven by the need to support the less popular or well-known without concern necessarily for establishing an identity. Each one of these motives may be evident in supporting and/or identifying with the underdog; however, the second dimension should be less prevalent as unpopular choice counter-conformity hints toward antisocial behavior instead of the benign fun-lovingness associated with underdogs.

Another support motive for the underdog may be driven by the fact that people understand or empathize with the underdog's plight. Empathy is generally regarded as the ability to "know another person's inner experience" (Buie, 
Table I. Personal interview informants

\begin{tabular}{|c|c|c|c|c|}
\hline Name & Region & Age & Occupation & $\begin{array}{l}\text { Primary underdog } \\
\text { context described }\end{array}$ \\
\hline Mandy & Northwest & 33 & $\begin{array}{l}\text { Elementary } \\
\text { school teacher }\end{array}$ & School children \\
\hline Tony & East Coast & 66 & High school teacher & Business professionals \\
\hline Lana & East Coast & 68 & Retiree & Society in general \\
\hline Bethany & Midwest & 32 & Nurse anesthetist & Business \\
\hline Jo & Northwest & 46 & Office assistant & Business \\
\hline Jan & West Coast & 34 & Marketing executive & Business professionals \\
\hline Edward & Midwest & 42 & Computer specialist & Small market sports \\
\hline Norris & Midwest & 42 & Professor & International sports \\
\hline Shanna & Midwest & 51 & Office assistant & Society in general \\
\hline Latricia & Midwest & 56 & Insurance auditor & Interscholastic sports \\
\hline Ben & Midwest & 56 & $\begin{array}{l}\text { Communications } \\
\text { specialist }\end{array}$ & Professional sports \\
\hline Sylvester & Midwest & 41 & $\begin{array}{l}\text { Copy company } \\
\text { manager }\end{array}$ & Professional sports \\
\hline Victoria & Midwest & 31 & Professor & Professional sports \\
\hline Sophia & Midwest & 38 & Professor & Society in general \\
\hline Milan & Midwest & 42 & Professor & Professional sports \\
\hline Petr & Midwest & 33 & Professor & College sports \\
\hline Orland & Midwest & 26 & Financial advisor & All sports \\
\hline Sasha & Southeast & 34 & Professor & Business \\
\hline Arnold & Midwest & 56 & Chemist & College sports \\
\hline Betsy & Midwest & 56 & $\begin{array}{l}\text { Elementary } \\
\text { school librarian }\end{array}$ & School children \\
\hline Tobin & Northwest & 35 & Sales rep & Society in general \\
\hline Ozzy & Northwest & 69 & Retiree & Society in general \\
\hline Maurice & Northwest & 42 & Computer specialist & Sports \\
\hline Carl & West Coast & 71 & Retiree & Society in general \\
\hline Alice & Northwest & 73 & Retiree & Society in general \\
\hline Billie Jean & Northwest & 34 & Student & Society in general \\
\hline Austin & Northwest & 52 & Rancher & Society in general \\
\hline
\end{tabular}

1981). "High-empathy, compared with low-empathy, subjects engaged more in altruistic behaviors, were less aggressive, more affiliative, rated positive social traits as more important, and scored higher on measures of moral judgment" (Mehrabian et al., 1988: 229). One who is empathetic, then, might identify with the plight of those who have had to try harder, work harder and perhaps longer in order to get to his or her current status. One who is empathetic should be more able to understand the plight of the underdog.

This study investigates the existence of the underdog phenomenon and attempts to provide insight as to the motivations for supporting the underdog. The underdog phenomenon is of interest because this phenomenon may explain why consumers actively choose to purchase or frequent or root for stimuli that are well-acknowledged (maybe even by the underdogs themselves) as not being the best alternative in terms of quality, price, or both.

\section{Method}

The first author interviewed, both over the phone and in-person, 27 individuals of various ages, educational backgrounds, occupations, and geographic locations (see Table 1) in the United States. Approximately three-quarters of the interviews were conducted in-person, while the rest were con-
Table 2. Focus Group Informants

\begin{tabular}{llll}
\hline Name & Region & Age & Occupation \\
\hline Roland & Northwest & 39 & Pharmacist \\
Todd & Northwest & 39 & Pharmacist \\
George & Northwest & 38 & Engineer \\
Sommer & Northwest & 40 & Housewife \\
Joline & Northwest & 41 & Nurse \\
Sabrina & Northwest & 35 & Preschool teacher \\
Paul & Northwest & 35 & Delivery driver \\
Jim & Northwest & 36 & Rancher \\
Kiera & Northwest & 35 & Student \\
\hline
\end{tabular}

ducted over the phone. Informants were identified through friends, colleagues, and acquaintances. The ages of the participants ranged from the mid 20s to early 70s and consisted of blue collar workers, professionals, and retirees. Participants were from the northwestern, midwestern, west coast, and east coast regions of the United States. In addition, a focus group was conducted with nine people of similar backgrounds (see Table 2). Thus, in total, 36 individuals participated in the study. Focus group participants ranged in age from mid 20s to early 40s, and included blue collar and professional workers. All focus group participants resided in the northwestern region of the United States. The primary purpose of the focus group was to determine whether other areas of exploration remained. The resulting data, however, converged with the individual interviews.

Initially, the authors sought individuals who were selfproclaimed underdog sports supporters as the primary participant criterion. The first several interviews found the term "underdog" for the informants to extend beyond the realm of sports. The researchers therefore let the participants discuss the context they thought was most relevant to "underdogs," thus broadening the concept's context. Interviews took between 30 and $75 \mathrm{~min}$. Both authors reviewed, coded, and analyzed the verbatim transcripts. Informants were not paid for participation in this study. The need for further interviews ceased when the authors reached saturation, a point where unique findings were no longer being obtained under the current interviewing procedure (Glaser and Strauss, 1967; Strauss and Corbin, 1998). The authors compared findings with each other whereupon areas of convergence and divergence were analyzed.

Interviews began with "grand tour" (McCracken, 1988) questions around definitions of underdog, where they occur, and why informants find them intriguing. Early interviews were reviewed and used to guide additional areas of exploration for future interviews. The goal of this data collection method was to elicit detailed accounts and narratives of people's notions of underdogs, underdog support, the processes used to rationalize support, and the parameters placed upon support. The interviews were informed by literature in such areas as postmodern consumption, anticonsumption, and consumer identity projects. The alternating process between data collection and analysis through the examination of relevant literature is a suggested part of the immersion process indicative of grounded theory designs (Strauss and Corbin, 1998). 
The authors used a grounded theory method in generating concepts and categories (Glaser and Strauss, 1967; Strauss and Corbin, 1998). Open coding was used, which begins with creating abstract representations of "events, happenings, objects, and actions/interactions" (Strauss and Corbin, 1998, p. 102) that are identified as being important in the data. The different types of underdog support and ways in which people identify and show affection toward underdogs in a variety of contexts dominate the data. The next step in the open coding process involves grouping concepts into categories, or what Strauss and Corbin (1998) call "discovering categories."

\section{Findings}

\subsection{Underdog meanings}

The literature review suggested that people distance themselves from less successful entities in order to save face (Cialdini et al., 1976). The findings suggest that underdog supporters actively and enthusiastically support underdogs without social consequence by framing and substantiating their support in socially desirable ways. However, while the informants talked at length about underdog individuals, teams, brands, and stores, they did not respond to stimuli such as stocks or politicians. The informants describe the underdog in a "less than" fashion, but ultimately resolve cognitive dissonance (Festinger, 1957) by framing the underdog as an entity that has positive attributes, such as persistence in the face of overwhelming odds. Thus, they appear to attribute the poor performance to lack of ability as opposed to lack of effort. Their perception of the underdog is more noble and unique and one that shows compassion, genuine loyalty, and determination, all of which compensate for any negativity associated with losing.

Being "less than" is in standing opposition to the top dog, and informants perceive "underdog" to mean less privileged, less popular or known, less likely to win, and less well equipped. Being "less than" emerged as the major descriptor of underdog, and in most cases, the informants inevitably discuss how underdogs are entities that have redeeming value. Some responses centered on the idea of being physically or mentally challenged but succeeding or overcoming despite these liabilities. Some of the informants described a state of having fewer skills, having fewer inherent advantages, being from a less privileged status, or being oppressed. To Sophia, an educator in her late 30s, an underdog means the following:

I think of it [underdogs] as groups that are considered oppressed... people of color, transgendered, poor people, women (a short laugh in response to her own underdog status)... definitely disabled people, sometimes elderly people, but they tend to be pretty empowered these days. Those would be the main ones. (Sophia)

Similarly, Tobin, a mid 30s salesperson, said the underdog is, "Someone who has [fewer] opportunities than the other guy, less education, less physical ability...." A "less-than" theme also emerged when the informants described situa- tions in which the underdog person was one whom nobody wanted or supported, and was left behind by everybody else. Several informants (Carl, Ozzy, Tobin, and Mandy) described situations in which the underdog was undoubtedly the last person to be chosen for sides in school. Carl, a retiree, gave us the following account:

[An underdog is] the person that if you are choosing up sides or choosing up players for a baseball team, it is the person that is chosen very last with not much support... maybe a person of a different race or creed that doesn't fit in with the rest of the group. (Carl)

Edward, a computer specialist in his early 40s, described underdogs as teams that were less popular which, from his perspective, was related with those from small media markets, and with those teams lacking a tradition of success:

When I think of an underdog I think of K-State (Kansas State University), and the Kansas City Royals versus the Yankees." (Edward)

Of all the descriptions of what an underdog is, the most prevalent response focused around the idea of being less expected to win a match, contest, or game. In this regard, many informants first placed the underdog within a sports context, commenting that it is usually the lesser athlete, team, or contestant that was not favored to win the match or contest as the underdog. To a lesser extent the informants discussed how underdogs are less likely to win or succeed in life. They described conditions that were beyond the underdog's control that rendered them less prepared to handle the complexities and challenges of everyday life. Petr, a foreignborn business professor, commented that underdogs are those "flying under the radar."

Another dimension that defined the underdog was its strong will or indefatigable spirit, an attribute that marketers in the United States have successfully used in campaigns (Holt, 2004). An entity lacking this characteristic not only made the informants cease support, but this characteristic also served as differentiator between underdogs and simply losers. Given how the informants in this study defined the underdog as one who is determined and never gives up, at least in the minds of the study informants the psychological connection they make with the underdog has little to do with losing and more to do with the more desirable trait of persistence and fighting against the odds. In describing the difference between an underdog and loser, Ben, a computer specialist in his mid 50s, said the following:

The difference between a loser and an underdog is that "loser" is a pejorative and "underdog" is an affirmation of some kind. It's a statement of love as opposed to, typically, a loser [which] is a statement of distaste. (Ben)

Ben's statement alludes to the notion of control, and whether a person or entity tries to change their conditions. Attribution theory suggests that people will search for causes of events and decide whether the outcome was controllable or due to outside factors (Heider, 1958; Kelley, 1967). Research suggests that consumers tend to get emotional when 
people or firms (Morales, 2005) do not live up to their moral obligation to work and to try hard, and therefore will punish them for their lack of effort by possibly ceasing their support (Weiner, 1974). On the other hand, they will reward and support those who do demonstrate effort. In regard to underdogs, people like Ben will not identify with underdogs if they view their losing as due to lack of effort, but will identify with underdogs if they view losing as due to less ability. This finding is similar to Thompson and Arsel's (2004) anti-corporate coffee shop consumers who find comfort in the local coffee shops' lesser atmospheres because they attribute these environments to lack of financial resources, not lesser effort.

Latricia, an insurance auditor in her mid 50s, alluded to this distinction as well. She said that she will not root for the underdog simply out of sympathy; elements of heart and spirit have to be evident as well. She emphasized the following:

I would have to see a work ethic. They would have to show me that they have some ambition to do something other than they're the underdog and everybody's supposed to feel sorry for them because they're the underdog and help them because they're the underdog. ... God helps those who help themselves. ... You've got to work at whatever you do. If you're good, then get better. If you're bad, get better. (Latricia)

Thus, underdog supporters see a need to attribute "less than" outcomes to a lack of ability in order to maintain their support; lack of effort appears to be associated more with "losers."

Overall, the comments regarding the underdog converged tightly. The informants saw the underdog in opposition to a superior opponent in the context of an athletic competition. Given how the informants in this study defined the underdog as one who is determined and never gives up, the psychological connection they make with the underdog has little to do with losing and more to do with the more socially desirable trait of persistence and fighting against the odds.

\subsection{Underdog motives}

Underdog consumers are ones who are emotionally driven, which makes intuitive sense based upon the fact that their choices often go against the grain. As such, their motives are replete with emotional directives that may seem to fly in the face of rational thought. The underdog consumer is one who has had to deal with sudden shifts or disruptions (Holt, 2004) in the environment and is therefore understanding of the social demands placed upon succeeding. But like the underdogs $\mathrm{s} /$ he supports, the underdog consumer knows that success is difficult to achieve but will continue to support the underdog despite the high probability of ensuing disappointment. The motives or causes of underdog support are listed in Figure 1. All relationships leading to underdog support are positive.

In many situations, the informants placed themselves in the position of the underdog by describing themselves as having been or being underdogs in some context, by launching into feel-good narratives about a time when they too felt "less than." When asked why she continues to be loyal to K-Mart

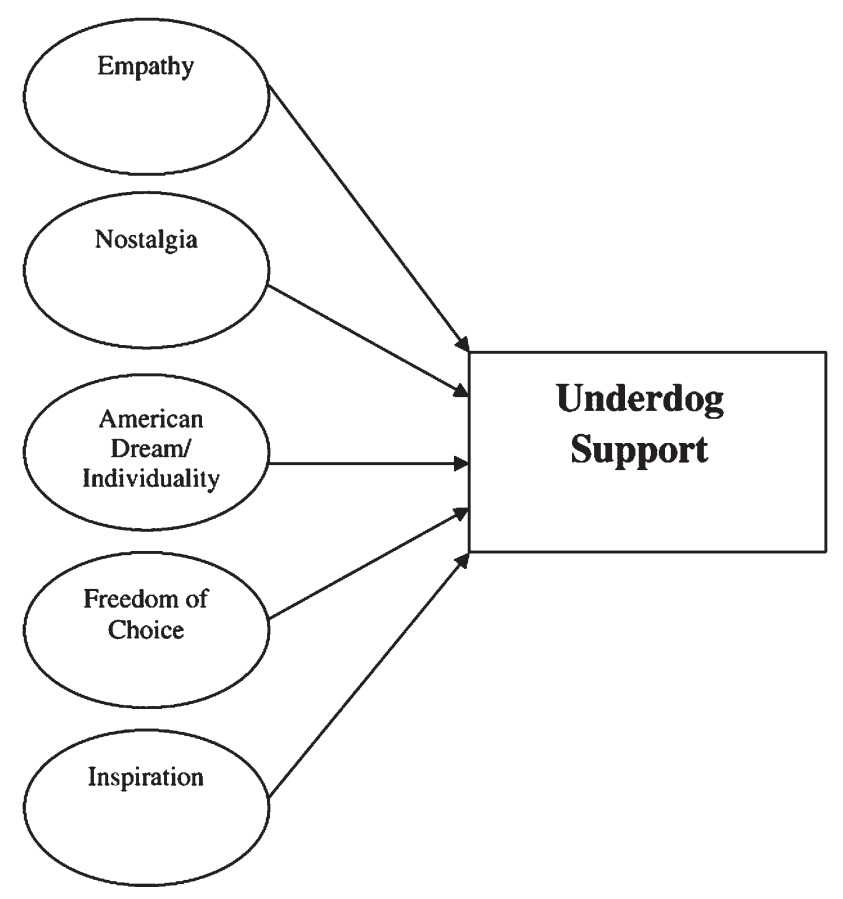

Figure 1. Conceptual model for underdog support motives.

despite the undeniable pull of Wal-Mart, Jo, a health administrator in her late 40s, explained that she supports the underdog K-Mart because her support helps keep Wal-Mart in check. Her support for K-Mart was passionate, emerging from feelings from her childhood when her mother used to take her to K-Mart on shopping trips. Asked to describe these stores in human terms, she described K-Mart as warm, comfortable, caring, and familiar, like a Grandma. Wal-Mart was described as outgoing, competitive, and vengeful. Her description further indicated that she enjoyed shopping at the older underdog-type stores because doing so made her feel good and, in a way, helped restore her youth. She felt a sense of nostalgia going to K-Mart, which is a common response among consumers utilizing brands from yesteryear. That is, consumers form enduring preferences for items that were consumed during their youth (Holbrook, 1993). Her need to support K-Mart was driven less by countercultural motives, as those found in Holt (2002), and more by the desire to reconnect with positive associations. This nostalgic perspective was also noted by informants in Thompson and Arsel's (2004) study who faulted Starbucks' inauthenticity as reflected by its willingness to change with consumer preferences and by one informant who criticized a local coffee house for remodeling.

When many of the informants were questioned more deeply to think about why they support underdogs or why they support specific restaurants or brands, they often described supporting the less privileged or the "moms-andpops" because they wanted the underdog to prevail or at least keep its head afloat. Some saw that this support would maintain balance and fairness by keeping the bigger businesses and established brands at bay. This support is similar to the anti-elite fanaticism found in Holt's (2004) description of Snapple's success and also reminiscent of the oppositional localists found in Thompson and Arsel's (2004) study, 
who clamor for more local, convenient alternatives to compete against Starbucks" "rapacious" expansion, and who use the local coffee shops to "enact a progressive vision of a just and sustainable economy" (p. 637). Deeper analysis of informants' remarks also reveals that support for the mom-andpops helps maintain a sense of individuality.

We are all individuals [in the United States]. We all want to stand out, but we pull together and we are cohesive when we need to be. You can walk into Dillard's in Kansas City and Dillard's in Washington DC and they're going to have the same products, but you walk into a little store in Lawrence, Kansas and it's all different and that just pulls at your heart. It makes you want to support that environment. (Bethany)

Bethany's description explains why people feel passionately about supporting local businesses, even though they might have a difficult time assessing why they feel the need to support individuals from the community whom they do not know. Bethany, a nurse anesthetist in her mid 30s, did not know the owners of the places she described, but felt compelled to support them anyway. Asked why, she said because they are a part of the community. Acknowledging that large chain store workers (such as those from WalMart) are part of the community, too, she further explained that the motive of her support was driven by the fact that people who demonstrate risk and individuality need to be rewarded. When asked if supporting the underdog business spoke to her as an American, she explained:

Yes, it does. Back in the early 30 s and 40 s, back before the whole franchise thing started, everything was mom-and-pop restaurants, mom-and-pop department stores. ...When all the national franchises and chains started coming in, it just started taking over that small business. (Bethany)

When the authors queried Lana, a retiree in her early 70s, for the reasons why she feels compelled to support underdog stores, she, too, went down the path of individuality. Her responses later revealed, however, that part of the "American Dream" is to succeed on one's own. When asked if the success one achieves by going through ranks of Wal-Mart is different from the success one can achieve on his or her own, she said:

I think our freedoms would be at stake with these big corporations. (When asked what types of freedoms, she further responded:) The American dream, the successful making it.... the pulling yourself up by your bootstraps (a pulling gesture is followed by a slight laugh). It's that dream that we have as Americans. It's freedom. People all over the world come here in the hope of realizing that kind of dream. (Lana)

Lana indicated further that she does indeed shop at WalMart, even though she knows her support for them "squeezes out the mom-and-pops." Her confession mirrored that of several of informants who on one hand suggested that Wal-Mart was the archenemy of the underdog, but on the other hand in- dicated that the selection, economic benefits, and convenience of Wal-Mart were too much to overlook. This apparent contradiction is also characteristic of Thompson and Arsel's (2004) café flâneurs, who dislike Starbucks' bland corporate environment but will go to the coffee shop anyway due to Starbucks' high level of quality and service.

Edward, too, acknowledged that Wal-Mart is not the underdog and also said that Wal-Mart is pretty much a friend of the working class. He had a difficult time discussing what Wal-Mart means to him, indicating confusion over this "big", but not so "big", issue.

Well, you know, typically I'd say people who go to Wal-Mart are more working-class. ... Yeah, I know a lot of people who go there. So yeah - and then you'll probably find some things at Wal-Mart that are-cater more to that, the working-class guy-the price conscious. So, maybe-I think there's a lot of things at Wal-Mart that kind of are like that. The Wrangler Jeans versus Lucky Jeans or something like that. You don't find designer clothing at Wal-Mart. (Edward)

Several informants described American ideals of individualism and freedom. The freedoms they described and wanted to protect appear to be embedded in the idea of psychological reactance (Brehm, 1966; Brehm and Sensenig, 1966). Few wanted the Wal-Marts of the world to usurp the "mom-andpops" because at a deeper level this domination would mean less freedom of choice and fewer chances to succeed as individuals in American society. The informants defied the paternalism of large corporate attempts of persuasion by supporting the underdogs. But despite their attempts to support the underdog, many informants rationalized that they still go to Wal-Mart because of substantial differences in price and selection, which creates some confusion as to whether Wal-Mart should be considered the underdog or top dog.

The support for Wal-Mart was an interesting conundrum. Some informants framed the enormous chain as an underdog, catering to the needs of the common person. Others described Wal-Mart as being the antithesis to the mom-andpops, an evil force that ruins the fabric of small communities. Rationalizing Wal-Mart as an everyday low price leader may help alleviate any disturbance the informants may feel in supporting the retail behemoth. Wal-Mart's underdog-type facade may indeed shelter the retailer from further criticism due to the fact that some people view Wal-Mart as a friend to the common shopper. This mixed perception of the market leader was also evident from Thompson and Arsel's (2004) informant Sandra, who admits going to Starbucks but hopes that her friends do not see her in the store. In any event, the desire to shop at mom-and-pops was at least equally driven by the notion to uplift the underdog's spirits rather than to demonstrate anti-consumptive behavior toward Wal-Mart.

For the majority of the informants supporting the underdog created an emotional high, a feeling that they, too, could rise to the challenge. While inspiration could also be an outcome or benefit of underdog support, several informants indicated that the inspiration motive was clearly a predetermined reason why they engage in underdog support. Many underdog consumers sought out underdog television shows, 
movies, stores, athletes, teams, and other entities in order to feel empowered. Alice, a retiree in her early 70 s, said she purposively seeks out television programs such as A\&E's "Biography," which commonly portrays underdogs, because they make her feel that anything is possible. When the authors asked Victoria, a professor in her early 30s, why she supports underdogs, she said supporting underdogs gives her "satisfaction in knowing that the underdog can succeed, and that there's a chance for you to succeed when you're in similar situations."

Two of the informants (Carl and Edward) used the metaphor "David versus Goliath" to represent this motive, which is an etic perspective reference noted by Thompson and Arsel (2004) as well. This biblical reference signified the notion that people support underdogs because they want to see the small man beat the big man. Sophia said, "I guess there is always some satisfaction just out of seeing the little person win." Arnold, an avid sports fan, said, "I think it is just human nature to [want to] see the underdog, the little guy, come up and kick the bully in the shins." These informants mentioned that their support for the underdog would often end, though, when the underdog suddenly became arrogant.

On the other hand, limited evidence suggested that some informants were more anti-top dog than pro-underdog. One focus group informant, Roland, said that his basis for supporting the underdog had more to do with dislike for the top dog rather than liking for the underdog. He cited specific examples of the joy that arose from watching well-known players, athletes, and entities go down.

I wonder if sometimes it's not so much rooting for the underdog but wanting to see the cocky side that thinks they're going to take it all [lose]. I probably enjoy watching more the non-underdog, the favorite, lose. It's probably more watching the favorite lose than the underdog win. (Roland)

Roland's inspiration was driven more by watching top dog teams like the Yankees lose rather than watching the underdog win. The Yankees to him represented a brand that, in essence, tried to bully its way into power and prosperity without worrying what was left in its wake; a brand that had become overly popular and therefore very difficult for one to use as a point of establishing differentness from other consumers.

When the authors probed some informants about when they would cease supporting or identifying with the underdog, a common response was when the entity achieved some sort of success and respect or when the underdog stopped trying. Previous support for a team or athlete would lose its uniqueness due to the fact that others had jumped on the bandwagon. This finding is consistent with the notion that North Americans generally have a need for uniqueness (Ariely and Levav, 2000; Snyder and Fromkin, 1977; Tian et al., 2001). Edward said that he felt like ceasing his support for one of his perennial all-time favorite underdog teams because "when your team does succeed and has pulled out a lot of success, sometimes you can start to disassociate yourself from them." He did not relinquish his support, however, because he did not want to be associated with a person whose support was based solely upon performance. None- theless, he considered dropping the team because he was no longer unique. In this case, data suggest a bandwagon effect with "unpure" fans following the former underdog, and informants now not wanting to be seen as top dog supporters. Holt's findings on iconic brands indicate that supporting struggling teams is a badge of honor because "followers view their loyalty as tangible proof of genuine relationship" (Holt, 2004, p. 141). Edward's support can also be seen as a form of unpopular choice counter-conformity (Tian et al., 2001), in that his motive for supporting his team is based on making a choice that is counter to group norms without worrying about social disapproval.

Supporting the underdog, irrespective of the context, also helps to establish fairness between the haves and have-nots, and allows competition to occur on a more level playing field. Jan, a marketing executive in her mid 30s, made comments in this regard, but still believes individuals have to take advantage of opportunities:

[I like] making sure that everyone has the same opportunities. ... giving everyone the same opportunity to have the same chance. You can only lead so many people, and then it is up to them to take advantage of those things that make it a level playing ground. (Jan)

One informant, Petr, commented that supporting the underdog kept the competitive forces alive and allowed the consumer to have the best products at the best prices. Support was made through his pocketbook:

Making a purchase makes a statement. ... I would want this company to be a good contender in the marketplace. I support competition very much, so I wouldn't just want this company to just exist; I want them to be strong in the marketplace so that they can compete with the leading companies. (Petr)

\subsection{Findings summary}

The informants in this study provide insight as to the definition of "underdog" and how that construct differs from "loser." Supporting the underdog appears in many cases to be a badge of honor, one that is somewhat devoid of defaming connotations, as consumers in this study do not think of their support in a negative way. Also, in some cases, support is driven by the need to be unique from other consumers in a way that is not all that concerned with others' approval, but not in an antisocial fashion either or in a way that intentionally seeks disapproval from others (Tian et al., 2001). The many possible reasons for supporting underdogs (summarized in Figure 1) provide insight as to how consumers can actively support a "less than" stimulus.

\section{Discussion}

The manifest motives used to describe underdog support appear to be quite varied. These support reasons are driven by excitement, to be contrary to the popular vote, or to con- 
quer the bully or Goliath. These were surface level attributes that generally emerged from the informants in a quick, less thoughtful manner. On a deeper level the underdog informants were trying to achieve balance and equity, most often stemming from a period in which they themselves were treated as underdogs.

A few informants described situations of risking self-esteem for supporting the underdog, but by and large the informants appeared to separate support for the underdog from their own self-esteem and mental health. One might expect social risk to be at stake given the findings from BIRG, where one tends to support entities that enhance one's selfimage. The informants in this study appeared to be unconcerned with this perception, opting instead to support the underdog for motives that went beyond feelings of social concern, and in some cases rooting or identifying with the underdog for the very fact that doing so established unpopular choice counter-conformity (Tian et al., 2001).

This research also indicates that some people choose major entities while others have an affinity toward relatively small players, including moms-and-pops. Much of that latter affinity has been attributed to an anti-Global Brand perspective (Holt, 2004). Such concepts as voluntary simplicity, which can be construed as opposition to consumption in general, may extend to animosity to global or major brands. These findings indicate that another side to this issue exists, in that consumers may be less repelled by major players than they are attracted to small or local or energetic or personally relevant minor players. The presence of the market-dominant competitors serves to provide this underdog segment with the opportunity to understand better what they appreciate about the underdog.

Thus, what may generally be labeled as "anti-corporate" behavior or "anti-consumption" may, in the case of preferences for underdogs, be "pro-non-corporate" or even "proconsumption" behavior. Admittedly, some reasons for supporting underdogs (especially those related to beliefs in equal opportunity and the assurance of freedom of choice) may be attributable (or at least associated) with negative perspectives of "corporate" entities, but some very strong positive attractions exist here as well. Underdogs can build on those positives without resorting to anti-corporate appeals that may come off as whining, behavior more likely to be associated with losers.

\section{Limitations}

As with most research based on a small number of informants, the representativeness of the sample is questionable. The sample, despite the inclusion of informants for other regions of the United States, is dominated by people from the Midwest. This region is noted for its strong work ethic, and the consistent finding of empathy with those who try harder may not generalize to other regions. Further, the belief that hard work will lead to people getting ahead in life is apparently more an American than a European belief (Economist, 2005), thus the findings may well not generalize across cul- tures. Also, the study began with an emphasis on underdogs in a sports context. While the authors soon realized that the underdog construct has a far broader domain than just sports and they altered the interview guide accordingly, the scope may have been somewhat narrow for the first informants.

\section{Conclusions and suggestions for future research}

The phenomenon of "anti-consumption" (or the more moderate "anti-corporate") does not necessarily mean lessened consumption or even negative reactions to global brands and/or huge big-box retail. Some consumers simply prefer the underdog to their much larger competitors. In many cases, they pay extra for this preference, especially in the context of local retailers who cannot match the supply efficiencies of retailers such as Wal-Mart. On the other hand, the Thompson and Arsel (2004) study investigated local coffee house customers likely to pay less than had they gone to Starbucks, where no such option as the "bottomless cup" offered by local competitors exists. Market embeddedness does exist in some retail environments, and the resulting social norms exacerbate the positive preferences for local retailers at the same time that they stimulate negative perspectives of large chain retailers.

Understanding underdog support should provide guidance to the "Davids" of the world in terms of competing successfully against the "Goliaths." Fostering "anti" sentiments toward larger competitors may have some short-run benefits, but these findings indicate that the lack of obvious effort on the part of underdogs may change their images to those of "losers." Pro-active efforts by underdogs are critical components which enable their supporters to identify positively with entities not likely to be proclaimed as "winners" by the masses. Additionally, visible effort will also help consumers maintain their beliefs that supporting underdogs helps to maintain equal opportunities for smaller entities while holding the top dogs at bay. Thus, the "Davids" of the world cannot survive and prosper merely by riding an "anti-corporate" wave. Future research should delve more broadly into local environments and uncover those activities and components that differentiate most effectively underdogs from losers. Study is needed to determine just how much of underdog preference is due to resentment toward "corporate" entities, and how much is due to strong attractions to the underdog itself. To the extent that the latter is more important than the former, pro-active positioning of the underdog may be far more effective than any anti-corporate style of positioning, even if done in a subtle fashion.

\section{Acknowledgments}

The authors acknowledge the contributions and support from Stacey M. Baker, Russell Belk, Athinodoros Chronis, Fleura Bardhi, Susie Pryor, and Tony Gao. The Washburn University Beatrice Grant provided funding for this research. 


\section{References}

Ariely and Levav, 2000 Dan Ariely and Jonathan Levav, Sequential choice in group settings: taking the road less traveled and less enjoyed, J Consum Res 27 (December 2000), pp. 279-290.

Brehm, 1966 James R. Brehm, A theory of psychological reactance, Academic Press, New York (1966).

Brehm and Sensenig, 1966 James R. Brehm and John Sensenig, Social influence as a function of attempted and implied usurpation, J Pers Soc Psychol 4(6) (1966), pp. 703-707.

Buie, 1981 Dan H. Buie, Empathy: its nature and limitations, J Am Psychoanal Assoc 29 (1981), pp. 281-307.

Cialdini et al., 1976 Robert B. Cialdini, Richard J. Borden, Avril Thorne, Marcus R. Walker, Stephen Freeman, and Lloyd R. Sloan, Basking in reflected glory: three (football) field studies, J Pers Soc Psychol 34 (3) (1976), pp. 366-375.

Economist, 2005 Economist, "An ode to failure," February 26, 2005, p. 36.

Festinger, 1957 Leon Festinger, A theory of cognitive dissonance, Stanford University Press, Stanford, CA (1957).

Fisher and Wakefield, $1998 \rightarrow$ Robert J. Fisher and Kirk Wakefield, Factors leading to group identification: a field study of winners and losers, Psychol Market 15 (January 1998), pp. 23-40.

Ger and Belk, 1996 Guliz Ger and Russell W. Belk, I'd like to buy the world a Coke: consumptionscapes of the less affluent world, J Consum Policy 19 (December 1996), pp. 271-304.

Glaser and Strauss, 1967 Barney G. Glaser and Anselm L. Strauss, The discovery of grounded theory, Aldine, Chicago (1967).

Grove et al., 1991 J. Robert Grove, Stephanie J. Hanrahan, and Adrian McInman, Success/failure bias in attribution across involvement categories in sport, Pers Soc Psychol Bull 17(1) (1991), pp. 93-97.

Heider, 1958 Fritz Heider, The psychology of interpersonal relations, Wiley, New York (1958).

Holbrook, 1993 Morris B. Holbrook, Nostalgia and consumption preferences: some emerging patterns of consumer tastes, J Consum Res 20 (September 1993), pp. 245-256.

Holt, 2002 Douglas B. Holt, Why do brands cause trouble? A dialectical theory of consumer culture and branding, $J$ Consum Res 29 (June 2002), pp. 70-90.

Holt, 2004 Douglas B. Holt, How brands become icons: the principles of cultural branding, Harvard Business School Press, Boston, MA (2004).

Kelley, 1967 Harold H. Kelley, Attribution theory in social psychology. In: D. Levine, ed., Nebraska Symposium on Motivation 15, University of Nebraska Press, Lincoln (1967), pp. 192-238.
Kozinets, 2001 Robert V. Kozinets, Utopian enterprise: articulating the meanings of Star Trek's culture of consumption, J Consum Res 28 (June 2001), pp. 67-87.

Kozinets, 2002 Robert V. Kozinets, Can consumers escape the market? Emanicipatory illuminations from burning man, J Consum Res 29 (June 2002), pp. 20-37.

MacInnis and de Mello, 2005 Deborah J. MacInnis and Gustavo E. de Mello, The concept of hope and its relevance to product evaluation and choice, J Mark 69 (January 2005), pp. 1-14.

Mann, 1974 L. Mann, On being a sore loser: how fans react to their team's failure, Aust J Psychol 39 (1974), pp. 37-47.

McCracken, 1988 Grant McCracken, The long interview, Sage, Newbury Park, CA (1988).

Mehrabian et al., 1988 Albert Mehrabian, A. L. Young, and S. Sato, Emotional empathy and associated individual differences, Curr Psychol Res Rev 7 (1988), pp. 221-240.

Morales, 2005 Andrea C. Morales, Giving firms an "e" for effort: consumer responses to high-effort firms, J Consum Res 31 (March 2005), pp. 806-812.

O'Guinn, 1991 Thomas C. O'Guinn, Touching greatness: The central midwest Barry Manilow fan club. In: Russell W. Belk, Editor, Highways and buyways, Association for Consumer Research, Provo, UT (1991), pp. 102-111.

Snyder and Fromkin, 1977 C. R. Snyder and Howard L. Fromkin, Abnormality as a positive characteristic: The development and validation of scale measuring need for uniqueness, J Abnorm Psychology 86 (October 1977), pp. 518-527.

Strauss and Corbin, 1998 Anselm Strauss and Juliet Corbin, Basics of qualitative research: techniques and procedures for developing grounded theory, Sage, Thousand Oaks, CA (1998).

Thompson and Arsel, 2004 Craig J. Thompson and Zeynep Arsel, The Starbucks brandscape and consumers' (anticorporate) experiences of glocalization, J Consum Res 31 (December 2004), pp. 631-642.

Tian et al., 2001 Kelly Tepper Tian, William O. Bearden, and Gary L. Hunter, Consumers' need for uniqueness: scale development and validation, J Consum Res 28 (June 2001), pp. 50-66.

Wann and Dolan, 1994 Daniel L. Wann and T. J. Dolan, Attributions of highly identified sports spectators, J Soc Psychol 134(6) (1994), pp. 783-792.

Weiner, 1974 Bernard Weiner, An attributional interpretation of expectancy-value theory. In: Bernard Weiner, ed., Cognitive views of human motivation, Academic Press, New York (1974). 